\title{
Situační analýza a role diskurzů v sociálněvědním výzkumu'
}

\section{Situation Analysis and the Role of Discourses in Social Research}

\author{
Markéta Košatková
}

\begin{abstract}
The article introduces situation analysis (cf. Clarke 2005) as an epistemologicalontological basis for science freed of the positivistic paradigm. Situation analysis in a broader perspective dives into present discourses as well as discourses that have been concealed. At the meso-level, the analysis offers insight into social and discursive arenas formed by collective actors, key material elements, social organizations and institutions. At the micro-level it is aimed at the position of individual actors in a situation. Situational analysis provides multidimensional research resonating marginalized discourses and supports the everydayness of knowledge in a socially engaged, emic research of social reality. The focus on language constructions in the humanities allows for the re-definition of one's own entities, formulas, and rules. Their (im)possible transgression is a necessary response to the accelerated and diverse shape of the recent globalized and particularized society.
\end{abstract}

KEYWORDS situation analysis, re-presentation, discourse, methodology, qualitative research

\section{Úvod}

Situační analýza (SA) reprezentuje teoreticko-metodologický př́stup, který je systematicky rozvíjen americkou emeritní profesorkou sociologie a výzkumnicí Adele Clarke (2003, 2005, 2014, 2015, 2016, 2019). Do českého prostředí promlouvá situační analýza metodologicky orientovanou statí Kalendy (2016); návrhem integrujícího př́stupu při studiu kolektivní paměti (Karger 2017); sondou do somatických a psychosociálních aspektů partnerského soužití jedinců s tělesným postižením (Hanková a Vávrová 2017); pedagogickou studií domácí prípravy anglofonních dětí na vyučování (Venterová 2018); analýzou situace mnemonické praxe mládeže (Karger 2019)² či výzkumy v sociální práci (Kissová et al. 2018; Stanková 2020).

Sociální studia / Social Studies 1/2021. S. 35-52. ISSN 1214-813X.

1 Př́spěvek vznikl v rámci projektu GAČR Cesty k inkluzivní škole 21. století: etnografický př́stup, GA19-13038S, 1/2019-12/2021.

2 Z nabízeného výčtu je zřejmý vliv „zlínské školy situační analýzy“ na domácí produkci. 
SA principálně navazuje na nedostatky³ zakotvené teorie (Strauss a Corbin 1999), která několik desetiletí vévodila kvalitativním analýzám. Metodologický posun SA je patrný v 1) odklonu od pozitivistické rigidity, 2) důrazu na reflexivitu výzkumného procesu, 3) přizváním vlivu kultury na konstituci identity (srov. Suddaby 2006; Clarke, Friese a Washburn 2015; Kalenda 2016a) a 4) zapojením diskurzů a materiálních elementů. Zakotvená teorie, především v pojetí Charmaz (2000), a stejně tak situační analýza mají své kořeny v sociálním konstruktivismu, prostřednictvím čehož mohou zkoumat nejrůznější perspektivy sociálního bytí ve vztahu $\mathrm{k}$ prostředí a diskurzům.

SA reaguje na poststrukturalismus a interpretativní, postmoderní (diskurzivní) obrat ve vědě a přiznává výzkumníka jakožto element ovlivňující situaci (Clarke 2003). Svým komplexním zaměřením rozšiřuje pohled kvalitativní analýzy na zkoumanou situaci a respektuje složitosti a variace $\mathrm{v}$ získaných datech, včetně zohlednění živých i neživých aktérů a inherentních diskurzů. Zkoumaná situace je poté empiricky konstruována prostřednictvím nástrojů SA, které budou popsány níže (Clarke 2005). Právě širším úhlem pohledu, kterým na zkoumanou situaci nahlížíme (makro, mezo, mikro), můžeme v našich datech objevit spojení, která se zpočátku mohou jevit jako kontraintuitivní.

Prostřednictvím SA v kombinaci se symbolickým interakcionismem a foucaultovskou teorií diskurzu pohlíží výzkumník na zkoumanou situaci jakožto na kontextuální celek volně orámovaný designem vlastního výzkumu (tzn. situace není vyčerpána zcela, ale je ohraničena limity zvoleného výzkumu). Konceptuální infrastruktura SA (celostní pohled) pracuje s rozborem komplexní situace (nikoli se zaměřením na určité jednání vybraného aktéra). Díky tomu může být analytický proces zaměřen na nejrůznější datový materiál, čímž je zvýšena heterogenita dat a redukována míra simplifikace. Přizváním ne/diskurzivních dat a ne/materiálních aspektů je umožněno sledovat zkoumanou situaci komplexněji, včetně relevantních vztahů mezi jednotlivými elementy v ní identifikovaných. Ty jsou empiricky utvářeny prostřednictvím kartografických nástrojů SA v podobě map a poznámek. Komplexní zaměření „umožňuje zachycovat i unikátní a partikulární elementy, na které nemusí být brán zrretel, pakliže se výzkumník již od počátku soustředí pouze na jeden hlavní jev“ (Kalenda 2016a: 466). Výsledkem SA je porozumění a deskripce těchto vztahů.

Zahrnutím všech aktérů v situaci lze analyzovat mocenské struktury a tím obohatit epistemickou/ontologickou složku výzkumu. Nahlížení na složité situace z různých perspektiv a pozic nás dělá senzitivnější k diskurzu, který sami (např̀. z pozice výzkumníka) utváříme. Výzkumník se tak stává produktem a producentem vědomostí, a tedy dalším aktérem

3 Pojem nedostatky nemusíme brát nutně v negativním světle. Sama Clarke přiznává, že zakotvená teorie se různí v pojetí Glasera (1992), který zastává objektivistické paradigma, od př́stupu Strausse a Corbin (systematické pojetí). Autorka pracuje s metaforou dvou deštníků. Jeden střeží pozitivistický př́istup, kam řadí práci Glasera, druhý deštník je zastoupen konstruktivistickým či interpretativním proudem, do kterého je řazena práce Strausse a Corbin (1999) a Kathy Charmaz (2006). Clarke spolu s Charmaz v 80. a 90. letech začaly rozlišovat mezi pozitivistickou zakotvenou teorií (objevování a hledání významů) a konstruktivistickou (utváření významů) zakotvenou teorií. V práci Strausse silně vystupuje i pragmatistické prizma, která je pro Clarke inspirací. Její př́stup je tak spíše přirozeným vývojem a inovací pod vlivem nových prŕstupů v kvalitativním výzkumu. Situační analýza je spíše rozšířením než odmítnutím podstaty zakotvené teorie (srov. Clarke 2007). 
zkoumané situace. Dle Clarke (2005, s. 301) totiž není možnost, jak stanout mimo diskurz, náš vlastní nevyjímaje.

Kvalitativní př́stup představovaný $\mathrm{v}$ rámci monotematického metodologického čísla Clarke pojmenovává jako „balíček teorií a metod“ (Fletcher a Clarke 2018: 230). Z toho důvodu budeme popisovat metodologická východiska prrístupu i sledovat konkrétní metody situačně orientovaného výzkumu. Cílem prezentovaného textu je 1) představit teoreticko-metodologický posun SA od zakotvené teorie se zaměřením na rovinu diskurzů a 2) diskutovat limity, výzvy a potenciál metody v českém a zahraničním sociálněvědním výzkumu.

\section{Teoretické ukotvení metodologického přistupu}

Ontologickou osou strukturující přemýšlení v situační analýze je symbolický interakcionismus (Blumer 1969), který spolu s konstruktivistickými a diskurzivními př́istupy představuje teoretickou základnu situační analýzy. Základní tezí symbolického interakcionismu je analýza subjektivních významů, které aktéŕi pomocí interakcí re-produkují. Interakcionistické pojetí výzkumu se zaměřuje na pozici sociálních aktérů v „pomyslné síti vztahů, ve kterých se př́mo-reálně či symbolicky nachází“ (Vojtíšková 2008: 62).

Poznávání sociální reality je principem vědy. Postmodernisté k poznání přidávají oproštění od touhy předávat a produkovat trvalou pravdu, čímž se zbavují traumatu objektivismu. Místo toho nabízejí relativizaci pravdy a sdíleného vědění a přicházejí se subjektivním, reflexivním pojetím vědy a jí produkovaným věděním (srov. Gergen 2008). Výzkumník je v SA součástí celého procesu a jeho předporozumění zkoumané situaci by mělo být reflektováno (stejně jako pozice vzhledem k participantům výzkumu či selekce klíčových elementů, témat a vztahů). Subjektivita výzkumníka není zamlčována ve snaze vyhovět pozitivistickým regulím, ale záměrně přizvána do analyticko-interpretačního postupu.

SA do výzkumného procesu zapojuje zájem o utváření významů $v$ jednotlivých diskurzech a jejich roli v sociální realitě. Důležitou perspektivou je optika samotných aktérů, jejich vnímání a rozumění situaci. Konstrukce významů je jazykově utvářena, stvrzována a re-produkována. Právě zaměření na jazykové utváření reality je jedním z vodítek, jak pozorovat sociální fenomény a mechanismy interakce ve společnosti. Kritika saussurovského pojímání pevné struktury jazyka přivedla poststrukturalisty $\mathrm{k}$ interakční a relační povaze jazykového označování. Clarke přebírá od diskurzivních výzkumníků zájem o společenský konsensus, vzorce, které jsou historicky, kulturně a sociálně determinovány. Analytickou jednotkou je situace a její významy a konstrukce zkoumané reality jednotlivých aktérů situace. Důležitým prvkem jsou vztahové procesy, které akcelerují tvorbu situačně ukotveného vědění.

Clarke (2003) nově pracuje s materiálními elementy (např. kultura, technologie, symboly, média) a diskurzy. ${ }^{4}$ Tímto rozšřřila dřive silně orientovanou analýzu zakotvené teorie,

4 Foucault v Archeologii vědění (2002) zahrnuje do diskurzu veškeré kličové praktiky, které mají diskurzivní aplikaci, avšak ne nutně podobu verbální komunikace. Ty Foucault označuje jako praktiky nediskurzivní. Foucault tak nepřímo podnítil u řady autorů zájem o vizualizaci diskurzu, o vizuální a materiální objekty nesoucí význam (srov. Buckingham 2011; Rose 2012). Vizuální artefakty můžeme vnímat jako abstraktní nádoby sociální znalosti, které reflektují a reprezentují 
fixovanou na lidské chování. SA, podobně jako Latourův soubor materiálních a kolektivních podmínek konstruovaných entit, zkoumá nemateriální aktéry př́ítomné explicitně i implicitně v situaci. Jejich existence může být bariérou nebo výhodou pro různé aktéry (např. asymetrická pozice $\mathrm{v}$ př́istupu ke kapitálům). Právě zapojení diskurzů do zkoumané situace vnímáme jako největší prínos SA a zároveň jako značný metodologicko-epistemologický posun od zakotvené teorie ( $v$ textu prezentováno níže).

Interdisciplinarita ${ }^{5}$ je $\mathrm{v}$ situační analýze podporována vztahem $\mathrm{k}$ etnografii, která umožňuje sledovat kulturní, jazykové, sociální konstrukce a materialitu v každodennosti. Odkazuje k rutinním prvkům tvořícím sdílené vědění (Giddens 2007). Každodenní realita je esenciální realitou vytvářející referenční rámec našeho jednání, které vychází z habitualizovaných vzorců. Sociální realita je tvořena činnostmi, které jsou skutečné díky logickému ukotvení myšlenek udržujících přirozenost vlastního světa (Berger a Luckmann 1999, s. 25). Každodennost vědění odkazuje $\mathrm{k}$ intuitivnímu vědění, které je propojeno s jednáním, myšlením a jazykem. Jedná se o jakési praktické vědění, jímž disponujeme, aniž si je plně uvědomujeme. Zároveň je toto vědění ovlivňováno působením kulturních a diskurzivních praktik širšího okolí, naší sociální reality. Každodenní zkušenost čerpá z uloženého kategoriálního systému, který nám pomáhá tř́́dit koncepty a následně usnadňuje naši orientaci. Mysl a tělo jsou propojeny, emoční zkušenosti jsou somatizovány (Lakoff a Johsnon 1999, s. 75-90).

\section{Komplexnost situace před jednostrannou kauzalitou}

Na tomto místě budeme diskutovat hlavní posun situační analýzy od zakotvené teorie. Epistemologická linie směřuje od pozitivistického/realistického rámce myšlení (zakotvená teorie) $\mathrm{k}$ interpretačnímu, relativistickému paradigmatu vědy (situační analýza). SA přináší zaměření na senzitivní koncepty spíše než formalizující a generalizující teorie. Srovnání, které prezentuje následující tabulka 1 , nám pomůže se zorientovat ve východiscích situační analýzy, která se snažila reagovat na kritiku zakotvené teorie. Nejedná se o bipolární vymezení se (bud' - anebo), ale spíš o kontinuitu př́istupu, který ke společnému základu (např́ílad proces úvodního kódování) přidává další možnosti a nástroje poznávání zkoumané situace.

Základní jednotkou analýzy je situace, která je charakteristická množinou všech elementů ovlivňujících zkoumaný fenomén. Clarke (2007) se svým návrhem distancuje od př́lišné kauzality podporované např́íklad axiálním kódováním. Naopak zdůrazňuje adekvátnost i odlehlých, marginálních výsledků, které nemusejí být z analýzy vypuštěny pro jejich malý výskyt. Obecně tak staví na dobré praxi první generace zakotvené teorie, kterou transformuje větší flexibilitou postupů při sběru dat (jako př́klad můžeme uvést rozhovory, pozorování, vizuální data jako fotografie nebo video či diskuse na sociálních sítích) i interpretaci. Kontext př́ŕcinných podmínek jednání (zakotvená teorie) nahrazuje zaměřením se na situaci.

určitou fragmentovanou sociální realitu zachyceného obrazu (Meyer et al. 2013). Materiály př́itomné v situaci jsou mechanickou formou reprodukce, protože obsahují vlastnosti, znalosti a další atributy s nimi spojené (Banks 2001).

5 Podrobněji o interdisciplinaritě situační analýzy pojednal Kalenda (2016b). 
Tabulka 1: Posun od zakotvené teorie k situační analýze

\begin{tabular}{|c|c|}
\hline Zakotvená teorie & Situační analýza \\
\hline Zkoumání omezeného jevu & Zkoumání komplexní situace \\
\hline Určování kódů a jejich dimenzionality & Hledání elementů a tvorba poznámek \\
\hline Užší definice kódu & Širší definice elementu \\
\hline Hledání společných jevů napříč rozhovory & $\begin{array}{l}\text { Hledání i zamlčených („,helping silences speak“) } \\
\text { informací }\end{array}$ \\
\hline Snaha o objektivitu (výzkumník je upozaděn) & Dưraz na reflexivitu výzkumníka (výzkumník je součástí) \\
\hline Pozice znalého subjektu & Relace mezi realitou a předmětem výzkumu \\
\hline Uspořádání do kategorií & $\begin{array}{l}\text { Prvotní neuspořádání elementů (možnost odhalovat } \\
\text { vztahy napríč celou situací) }\end{array}$ \\
\hline- & $\begin{array}{l}\text { Zapojení analýzy diskurzů (zaměření na moc), } \\
\text { nehmotných objektů (např. technologie, architektura } \\
\text { třídy nebo role materiální kultury) a jejich vztahů v situaci }\end{array}$ \\
\hline- & $\begin{array}{l}\text { Různé perspektivy a odlišné zdroje dat (rozhovory, } \\
\text { pozorování, analýza legislativních rámců, vizuální } \\
\text { materiál apod.) }\end{array}$ \\
\hline Indukce & Abdukce \\
\hline
\end{tabular}

Zdroj: (Clarke, Friese a Washburn 2015: 15)

Clarke s referencí na Foucaulta přikládá diskurzům v situaci velký význam. Právě v této diskurzivní modalitě zakotvené teorie spatřujeme v našem prostředí (zatím) chybějící výzkumnou aplikaci. Diskurzivní př́stupy $(\mathrm{DP})^{6}$ a situační analýza nacházejí průsečík v exploraci významů diskurzů v sociální realitě. Jazyk sehrává klíčovou roli v procesu komunikace i konstituce vědění. Jeho performativní charakter umožňuje neustálou korespondenci mezi jednáním, sémiotickým systémem a následnou reakcí (znovu-jednáním). Jazykové zkoumání nám může pomoci rozumět každodennímu jednání a implikacím, které významně formují

6 Jednotlivé př́stupy jsou často spojeny s konkrétní autoritou, která vybraný diskurzivní př́istup v sociálních vědách plně etablovala. Zárodky DP lze spatřit v práci Ludwiga Wittgensteina a jeho filozofii jazyka. V sedmdesátých a osmdesátých letech minulého století diskurzivní analýza zastávala pozici interdisciplinárního prístupu, který byl oživen postmoderní teorií. V souvislosti s tímto obdobím máme na mysli diskurzivní obrat, který byl podpořen prací Michela Foucaulta a sociálním konstruktivismem (srov. Hjelm 2011). Začátkem devadesátých let se diskurzivní studie etablovaly mimo jiné díky př́nosu Teun van Dijka (1988) v samostatnou disciplínu. Hovoříme-li o diskurzivních př́stupech, máme na mysli celou řadu vzájemně provázaných i autonomních diskurzivních směrů - např. diskurzivní psychologie rozvíjená Jonathanem Potterem (2000); konverzační analýza (Tůma 2016; Wooffitt 2005; Sacks 1992) a kritická diskurzivní analýza (Wodak a Meyer 2001). Van Dijk (2006a, s. 1) dodává reflexi využití diskurzivní analýzy v jednotlivých oborech. Sociologové se jeho perspektivou začali věnovat interakcím v komunikaci; lingvisté zkoumají situovaný text a jazykové uživatele; žurnalisté se věnují mediálnímu a politickému diskurzu; antropologové se zajímají o společenské akce a jejich schopnost komunikovat; kognitivní psychologové se zaměřili na důležitost vědomostí a konečně sociální psychologové svoji oblast zájmu nasměrovali na sociální realitu, která je diskurzem utvářena. 
identitu člověka. Jazyk má v sobě zakódované sociální a kulturní determinanty. Luhmann připisuje komunikaci důležitou funkci, protože na základě ní vznikají sociální systémy (2006, s. 180). Diskurzivní prŕístupy pracují s variabilní sadou metod a teorií zaměrujících se na verbalizované vědění, které je typické pro určitou situaci, kontext či epistémé, budeme-li se odvolávat na Foucaulta (2002). Clarke přebírá diskurzivní př́stupy volně, bez pregnantního vymezení se vůči jednotlivým výzkumným proudům. Její prínos však spočívá v explicitním přizvání jejich působení do zkoumané situace.

Nástroje využívané v SA umožňují zkoumat situaci optikou třech úrovní (makro, mezo, mikro). Ačkoliv jsou některá témata více spjata s konkrétními úrovněmi zkoumání, finální výběr úrovně, na které bude daný element zkoumán, závisí na výzkumníkovi a na otázkách a tématech, které chce ve své zkoumané situaci zodpovědět. Tato skutečnost je v schématu 1 reprezentována prostupností mezi jednotlivými vrstvami.

Schéma 1: Jednotlivé úrovně v situační analýze

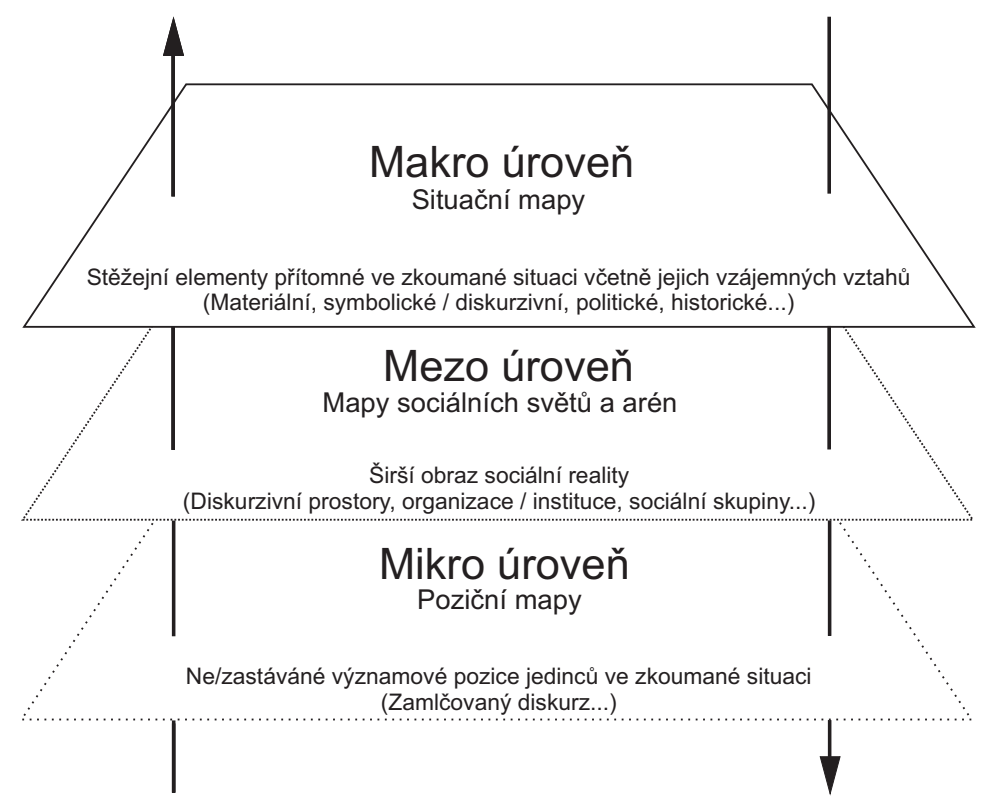

Vrchní vrstva (makroúroveň) zahrnuje širší diskurzy (např. feministický, rasový, globalizační, urbanizační, neoliberální, politický), které situačně (lokálně) vytvářejí pevné formace normality a rutiny. Působení disparitních (rozdílných) mocenských diskurzů v oblasti sociálněvědního výzkumu přináší antagonistické teorie; reformní vědecké enklávy či interakce mezi aktéry, sociálními skupinami a organizacemi.

Střední vrstva (mezoúroveň) směřuje svůj fokus na existenci sociálních světů a arén se zaměřením na organizační a institucionální charakteristiku výzkumně zpracovávaného 
fenoménu. Toto rozdělení je spíše exemplární, v praxi je potřeba počítat s prolnutím a flexibilitou jednotlivých hraničních vrstev, jak již bylo zmíněno výše. Sociálnímu světu můžeme rozumět jako kolektivní entitě, která sdružuje jedince s různými závazky vůči sociální realitě. Tyto závazky mohou být formálně organizované, nebo naopak existovat ve volném, informálním prostoru. Aréna představuje diskurzivní prostor pro různé světy, které se překrývají i vzájemně vylučují. Právě symbolické hranice, které jsou pro jednotlivé světy typické, mohou být zdrojem strukturálních nespravedlností, které jsou v diskurzivní aréně udržovány (Young 2007).

Spodní vrstva (mikroúroveň) umožňuje zkoumat různorodé významové pozice diskurzivních materiálů, rozhovorů, výsledků pozorování a reprezentovat jejich pozici zaujímanou v diskurzu se zachováním si svých vlastních podmínek. Na této úrovni často zkoumáme diskurzy, které nemusely být explicitně artikulovány, avšak signifikantně ovlivňují elementy ve zkoumané situaci. Tyto diskurzy ve schématu označujeme jako zamlčené.

\section{Tvorba elementů v situační analýze}

Pro tvorbu elementů je výhodné opatřit každý element souborem poznámek. Poznámky nám znázorňují vlastnosti a charakteristiky elementů a jejich vztahy. Element s odkazem na pojmosloví zakotvené teorie není kódem, protože obsahuje širší informace. Zároveň jej ale nemůžeme ani přirovnat ke kategorii. Je tedy něčím na půl cesty mezi kódem a kategorií. Element vzniká abdukcí. Většina situací je tvořena materiálními i nemateriálními elementy. Při stavbě elementu se díváme na jeho jazykovou reprezentaci, rozsah, koherenci i odlišnost.

Realizace analytické práce je dle Clarke organizována za pomoci tř́ tzv. kartografických nástrojů (2005, s. 12). V SA hovoříme o situačních mapách, mapách sociálních světů a arén a pozičních mapách. Závěrečnou vizuální sumarizací těchto tř́ nástrojů může být mapa projektová, která nese výsledný narativ výzkumného projektu.

Předstupněm analytické práce $\mathrm{v}$ situační analýze je mapa předpokládaných elementů situace, která slouží k podpoře reflexivity výzkumníka. Výzkumník si odpovídá na otázku: „Jaké elementy dle mého názoru vstupují do situace?“ Vedle vlastní sebereflexe může reflektivní mapa sloužit $\mathrm{k}$ zorientování se ve zkoumané situaci i ve vlastních myšlenkových schématech analyzované situace. Počáteční mapa elementů vzniká v ideálním př́ípadě ještě před vstupem do terénu a sběrem dat. Jak je tedy patrné, jde o dosavadní znalost výzkumníka, která je dost často ovlivněna teorií a studiem literatury. Tento krok je důležitý, protože zachycuje předporozumění výzkumníka a jeho teoretické koncepty, kterými je ovlivněn. Ukazuje očekávání výzkumníka před zahájením sběru dat. Umístěním výzkumníka do mapy lze sledovat jeho pozici, z níž manipuluje s daty. Zároveň se jedná o prvotní přehled situace, který $\mathrm{v}$ dalších fázích analýzy může pomoci při srovnávání a hledání abnormalit $\mathrm{v}$ teorii nebo legislativní/institucionální praxi a realitě samotných aktérů.

V prvním kroku kódování procházíme texty stejně jako v jiných kvalitativních analýzách. Jedná se o identické analytické strategie jako např. u otevřeného kódování (Strauss a Corbin 1999). Upřednostňováno je detailní čtení a kódování důležitých segmentů textu. Tímto způsobem lze kódovat kratší úseky textu, slovní spojení či jednotlivá slova. Takto 
nalezené segmenty pojmenováváme kódy, s možností využití in vivo ${ }^{7}$ kódů. Detailnější prací s kódy, jejich slučováním, porovnáním a poznámkováním vznikají první počátky elementů situace. Práce s poznámkovým aparátem jednotlivých nedokonalých elementi̊ je zásadní pro další analytické procesy. Výsledkem tohoto analytického kroku je prvotní neuspořádaná (messy) mapa. Pojem „prvotní“ je zde namístě, nebot’ „hotová“ verze neuspořádané mapy nevznikne napoprvé a při analýze dat je mapa neustále upravována a aktualizována. O mapě hovoř́me jako o neuspořádané, protože jednotlivé elementy se mohou měnit nebo lišit u jednotlivých respondentů nebo $\mathrm{v}$ dalších datech (nap̌r. mediálních textech či vizuálních re-prezentacích), a proto by jejich „násilné“ přiřazování a hledání př́íčinných podmínek mohlo poškodit další proces analýzy.

$\mathrm{V}$ následné fázi nalezené elementy situace třídíme do tzv. uspořádané mapy (ordered). Přiložená tabulka 2 znázorňuje predikční strukturační matici situace, kam nalezené nedokonalé elementy ( $v$ téhle fázi se ještě stále nejedná o hotový element) potenciálně spadají. Jedná se o další př́iležitost obohacení elementu o jeho detailní popis (poznámky). Takto uspořádaná a vizuálně strukturovaná mapa rovněž slouží pro přehlednější a snadnější orientaci mezi elementy.

Clarke (2005) doporučuje pracovat s následující maticí, která je dle ní charakteristická pro každou situaci. Uspořádání elementů podle matice může pomoci výzkumníkovi strukturovat množství proměnných, které do situace vstupují.

Tabulka 2: Elementy situace dle Clarke (2005)

\begin{tabular}{|l|l|}
\hline Individuální lidské elementy/aktéři & Neživé/materiální elementy/akce \\
\hline Např. klíčové postavy v situaci & $\begin{array}{l}\text { Např. informace, technologie, infrastruktura či hmotné } \\
\text { věci }\end{array}$ \\
\hline Kolektivní lidské elementy/aktéři & Zapojení/tiší aktéři \\
\hline Např. specifické organizace či skupiny & Dle zkoumané situace \\
\hline Diskurzivní konstrukty & Diskurzivní konstrukce neživých subjektů (aktantů) \\
\hline $\begin{array}{l}\text { Např. etnické a rasové stereotypy, gender, } \\
\text { pohlaví, sociální třidy }\end{array}$ & $\begin{array}{l}\text { Např. socioekonomický status, podobnosti/odlišnosti, } \\
\text { individualismus, standardizace }\end{array}$ \\
\hline Politické/ekonomické elementy & Sociokulturní/symbolické elementy \\
\hline $\begin{array}{l}\text { Např. politická uskupení, státní aparát, některá } \\
\text { prưmyslová odvětví }\end{array}$ & Např. náboženství, etnicita, symboly \\
\hline Dočasné elementy & Prostorové elementy \\
\hline Např. historické, sezónní, krize & Např. lokální, globální, geografické \\
\hline Hlavní otázky/debaty & Související diskurzy (historický, narativní, vizuální) \\
\hline Dle zkoumané situace & Např. morální a etické normy, specifické diskurzy, média \\
\hline Další druhy elementů & \\
\hline Dle zkoumané situace & \\
\hline
\end{tabular}

7 Označení in-vivo referuje k vyjádření samotných aktérů a má silnou vypovídající hodnotu samo o sobě. Ponechání kódu v in-vivo podobě zachovává jazyk komunikačního partnera (srov. Strauss a Corbin 1999; Charmaz 2006). 
Pro účely vlastního výzkumu je legitimní si předloženou tabulku upravit dle autorské analytické situace. Jinými slovy, není metodologickou chybou nepoužít všechny navrhované kategorie.

Ve třetí fázi již nepracujeme s předpřipravenou maticí, ale procházíme jednotlivé elementy a jejich poznámky. $\mathrm{V}$ této fázi může docházet ke sdružování elementů. Výzkumník dostává výraznější obrysy dané situace. Fáze také slouží pro kladení otázek, které vyvstávají z analýzy. Napřr. si můžeme uvědomit, že v datech se nenacházejí žádné materiální elementy. Ty často umožňují nebo znesnadňují lidské jednání v sociální realitě (viz nediskurzivní praktiky výše). Analyticky cenné je porovnání nalezených elementů z dat s počáteční reflektivní mapou situace, kterou výzkumník vytvořil ještě před samotnou prací s daty.

Třetí fáze nabízí pro práci s elementy nástroje v podobě jednotlivých map: situační mapy, mapy sociálních světů a arén a poziční mapy. Tyto (kartografické) nástroje jsou nejefektivnější, provádíme-li integrativní mapování/analýzu a/nebo komparativní analýzu, a to napříč různými zdroji dat (Clarke 2005, s. 176). Nástroje SA nabízejí širší paletu způsobů, jak lze analyticky zpracovávat získaná data a zároveň o nich dále uvažovat. Interpretace jednotlivých map lze řadit dle tematických linií, které vznikly v úvodu kódování.

Když poté jednotlivé mapy zkoumáme odděleně a výsledky následně komparujeme, ${ }^{8}$ můžeme si klást otázky typu: Jaké prvky se zdají být přítomny v různých oblastech zkoumané situace? Jaké diskurzy se v některé analýze objevují, a v jiné ne? Situační analýza nabízí flexibilní nástroje, prostřednictvím kterých můžeme provést re-konstrukci zkoumané situace na mozaiku, která je poskládána např́íc nejrůznějšími druhy diskurzů a jednání (Clarke 2005, s. 178). Pro účely výzkumu není nutné pracovat se všemi nástroji SA. Naopak Clarke (2003) doporučuje upřednostnit pružnost a variabilitu před pevnými postupy.

Jednotlivé nástroje SA v podobě situačních, relačních a pozičních map budou popsány dále. Zvláštní zřetel věnujeme mapám sociálních světů a arén, protože tento nástroj představuje výše nastíněné prolnutí diskurzivních prŕístupů a situační analýzy, v čemž shledáváme největší přínos SA a posun od zakotvené teorie.

\section{Relační analýza}

Vztahy mezi jednotlivými elementy, jež nám pomáhá určit relační analýza, rozšiřují situační mapu na mapu relační. Relační mapa nemusí zobrazit vztahy všech elementů, spíše se zaměřuje na silné vazby a ty zobrazuje. Obecně je doporučeno vybrat jeden hlavní element a ten popsat ve vztahu k ostatním elementům (klíčovou roli hrají poznámky). Oproti zakotvené teorii tak nevytváríme axiální model, ale můžeme vzít jakýkoliv element ze situace, ten stanovit jako výchozí element a začít hledat jeho vazby k ostatním elementům. Jedná se o princip neustálého srovnávání. Nalezené vztahy dopomáhají sledovat algoritmy, které konstruují situaci.

8 Pro komparaci může posloužit tzv. projektová mapa, která selektivně vybírá klíčové výsledky výzkumu (např. na základě konkrétního publika). Velmi zjednodušeně lze říci, že projektová mapa je jakousi „na míru“ vytvořenou kombinací map, které vznikly v průběhu výzkumu. Vizualizace dat pomáhá postihnout komplexnost zkoumané situace. 
Schéma 2: Fáze situační analýzy

\begin{tabular}{|c|c|c|c|}
\hline $\begin{array}{c}\text { Fáze } \mathbf{0} \\
\text { Reflektivní neuspořádaná } \\
\text { mapa před vstupem do } \\
\text { terénu. }\end{array}$ & $\begin{array}{c}\text { Fáze } 1 \\
\text { Neuspořádaná mapa } \\
\text { nedokonalých elementů } \\
\text { situace. }\end{array}$ & $\begin{array}{c}\text { Fáze } 2 \\
\text { Uspořádaná mapa } \\
\text { elementů situace. }\end{array}$ & $\begin{array}{c}\text { Fáze } 3 \\
\text { Další nástroje (relační } \\
\text { mapy; mapy sociálních } \\
\text { světů a arén; poziční mapy) }\end{array}$ \\
\hline
\end{tabular}

Při tvorbě relační mapy je třeba brát v potaz i takové elementy, jako jsou diskurzy, symboly, nápady a další důležité elementy ne/přítomné v situaci. Právě interpretace symbolů a diskurzů mají v analýze signifikantní význam. Z tohoto důvodu je při tvorbě relací mezi jednotlivými elementy důležitá funkce poznámek, nebot’ otázka: „Proč existuje vztah mezi těmito elementy?“ může být v relační mapě stejně tak důležitá, jako: „Proč mezi těmito elementy vztah není?" Relační mapy nám poté pomohou s rozhodnutím, na která témata - relace se ve výzkumu soustředit. Pro finální podobu mapy je klíčová saturace dat. Relační mapa, stejně jako všechny ostatní, projdou během svého vývoje mnoha změnami a revizemi. Samotný vývoj tvorby map je však již sám o sobě důležitou fází celkového procesu, nebot' elementy, které nebyly důležité dříve, a byly z naší mapy tudíž vyškrtnuty, mohou mít signifikantní význam později. To pouze deklaruje důležitost psaní (i na první pohled méně důležitých) poznámek v průběhu výzkumu.

Od situačních a relačních map, využívaných na makroúrovni výzkumu, se metodologický postup může přesunout na mezoúroveň $\mathrm{k}$ dalšímu nástroji $\mathrm{SA}$ - mapám sociálních světů a arén.

\section{Mapy sociálních světů a arén}

Ve výzkumu se většinou pokoušíme proniknout do sociálního světa vybraných aktérů (vliv chicagské školy). Snažíme se analyzovat prostředí a jeho dopady na chování, jednání a myšlení jedinců. Aréna je diskurzivní prostor věnovaný určitému tématu, který prostupuje různými sociálními světy. Situace jsou vždy rámovány existencí a praktikami různých organizací a sociálních skupin.

Mapa sociálních světů přestavuje rovinu organizací, cílových skupin a jednotlivých aktérů v nadhledu nad celou situací. Umožňuje zobrazit různé významové pozice klíčových jevů a aktérů z mezopozice, čímž překonává mikropozici typickou pro zakotvenou teorii (srov. Kalenda 2016a). Mapy sociálních světů jsou silně zakořeněny v symbolickém interakcionismu, který, stejně jako mapy samotné, neomezuje svoji optiku selektivně, ale soustředí se na situaci jako celek. Významy tak nevznikají pouze v rovině mezi jednotlivými lidskými aktéry. Strauss (1978) tyto sociální světy vnímá jako ,univerza diskurzů“. Diskurz jako takový proto v aréně není explicitně přítomen, nebot' sociální svět je jím sám reprezentován.

Cílem map je sledovat, jak jsou v aréně vytvářeny významy, které ovlivňují sociální světy v ní zahrnuté. Analýzou arén a jejich sociálních světů lze sledovat různé kolektivní aktéry, organizace a diskurzy, které arénu strukturují. Jelikož mapy umožňují prostupnost mezi jednotlivými vrstvami a strukturami, zviditelňují v nich jednání jednotlivých aktérů. 
V takovém př́padě je možné dojít $\mathrm{k}$ jejich deskripci na teoretické úrovni. Základním nástrojem/prvním krokem při utváření map sociálních světů je ohraničený teoretický rámec. Ten nám pomůže stanovit hranice mezi jednotlivými zkoumanými světy a také legitimizovat a dále prozkoumávat svět jako takový.

Při vykreslování diskurzivní arény nám pomohou následující senzitivní otázky:

1. Jaké je zaměření arény? Čemu se věnuje?

2. Jaká jsou tabu; klíčová témata; soupeřící vize; kontroverze $\mathrm{v}$ diskurzu dané arény?

3. Kde se nejčastěji aréna vyskytuje?

4. Kteří aktéri zůstávají $v$ aréně skryti?

5. Jaké jsou vzorce kolektivního jednání v aréně?

6. Jaké jsou sociální světy a jací aktéři jsou př́tomní v aréně?

7. Jaké sociální světy jsou implicitní v aréně? Co není na první pohled patrné?

8. Jaké relevantní sociální světy nejsou $\mathrm{v}$ aréně prítomné? Co je $\mathrm{z}$ arény vymístěno?

9. Jak se určitý sociální svět charakterizuje?

10. Jaké sociální světy a subsvěty spolu souvisejí a proč?

11. Existují nějaká slepá/tichá místa?

12. Jak je organizována agenda sociálních světů?

13. Jací neživí aktanti se vyskytují v jednotlivých sociálních světech?

14. Jaká omezení, př́ležitosti a zdroje lze v sociálních světech najít?

Mapy sociálních světů a arén zachycených na základě takto položených otázek nám posléze pomohou odhalit (třeba i nevědomou) participaci jednotlivých aktérů (ale i celých sociálních světů a organizací) v konkrétních sociálních strukturách, které zároveň sami (tř̌eba i nevědomky) tito aktéři utvářejí. Po vytvoření mapy sociálních světů a arén lze přistoupit $\mathrm{k}$ další úrovni zkoumání (mikroúrovni), popř. hlouběji zkoumat konkrétní sociální svět. Chtěli bychom podotknout, že samotné mapy nejsou konečným výsledkem analýzy, ale nástrojem, který analyticko-interpretační část pomáhá zachycovat. Klíčová je hutná interpretace elementů, diskurzů a sociálních aktérů identifikovaných v dané situaci.

Vizualizace arény umožňuje zachytit organizační úroveň kolektivních entit. Při tvorbě arény můžeme hovořit o rekonstrukci svébytných (diskurzivních) projevů různých makrosociálních a mikrosociálních světů, které tvoří zkoumanou situaci. Materiální i nemateriální elementy, kulturní prvky či diskurzivní praktiky představují intervenční jádro pro formování specifických vztahů a způsobů života dané skupiny, ale i celé sociální struktury. Grafické znázornění pomáhá vidět plasticitu dat a poodstoupit od jejich množství a variací.

Diskurzivní aréna pracuje s kritickým zájmem o tzv. inherentní etablované vědění. Zaměření výzkumníka na dominantní diskurzivní praktiky v aréně vede $\mathrm{k}$ výhradnímu typu vědění, které je šíreno, prosazováno, ideologizováno, nebo naopak zamlčováno. Tento typ vědění může být prosazován (př. objektivistické paradigma ve výzkumu) a následně sedimentován. Později je na něho pohliženo jako na axiom pravdy, který je nekriticky reprodukován. Pozice aktérů, kteří se v sociálním a diskurzivním poli nacházejí, odkazuje k jejich 
ne/možnostem symbolické mobility a $\mathrm{k}$ celospolečenskému ne/úspěchu. Odhalování jednotlivých pozic nám může ukázat diskrepance mezi jednotlivými aktéry, ale i alternativními diskurzy.

V tvrzeních sledujeme odkazy na naturalizované významy, odkazy na tzv. zdravý rozum neboli common sense. Jestliže mluvčí i konzument promluvy sdílejí stejné postuláty, zapadají informace do sdílených reprezentací reality. Van Dijk vyslovuje myšlenku o existenci mentálních modelů, které jsou kulturně strukturované, a přesto mohou být některé z modelů zcela univerzální (2006b). Zaměření na sdílené mentální modely a jejich zamlčené alternativní výklady pomáhá demaskovat určité ideologie - např. biologizující diskurz v otázce genderových rovností (Zábrodská 2009).

V datech lze analyzovat vymist'ující diskurzy o těch tzv. druhých, které představují diskriminující praktiky manifestované prostřednictvím jazykového označování. Konsekvence diskurzivního jednání mají konkrétní dopad na diskurzem marginalizované skupiny nebo jednotlivce (v našem př́padě cizince) a dostávají je tak do nesymetrických, mocensky podřazených pozic. Formy sociální reprezentace (např. mluvčí pražské kavárny; sluníčkář; muslimský terorista; nepřizpůsobivý Rom) implicitně připisují kategoriálně vázané rysy. Analýza odhaluje podřízené pozice, které mohou vznikat na základě tř́íních, rasových, genderových, náboženských a jiných mocenských bojů o př́stup $\mathrm{k}$ veřejným zdrojům. Ústředním pojmem je předsudek, který bývá zjednodušenou reprezentací člena opoziční, často zamlčené skupiny odlišných lidí. Zajímavé je sledovat diskurzivně přisouzená práva a povinnosti opoziční skupiny (dichotomii my versus oni).

\section{Poziční mapy}

Poziční mapy umožňují výzkumníkům zkoumat pozice jednotlivých aktérů ve vztahu k diskurzům, jiným osobám či organizacím a věcem, které jsou prrítomny v dané situaci. Spíše než vysvětlovat nekonzistentní výpovědi participantů odchylkami od normy, které by od výzkumníka vyžadovaly perspektivu konkrétních diskurzivních pozic, se poziční mapy snaží o pochopení a reprezentování dané situace na dvou osách, kterými jsou tvořeny. Jednotlivé pozice pak mohou být analyzovány $\mathrm{v}$ širším kontextu bez korelací se sociálním světem, a tudíž (více či méně) izolovány od stereotypizací a centrálních tendencí, nebot' právě soustředěním se na podobnosti spíše než na odlišnosti může být naše optika ochuzena o důležitý prvek heterogenity (Clarke 2005: 127). Poziční mapy představují pro výzkum nástroj, prostřednictvím kterého lze zaznamenat možné pozice, které zůstaly ne/záměrně zamlčeny. Prvním krokem při tvorbě poziční mapy je vyjasnit si otázky ve zkoumané situaci, které můžeme transformovat a rovnoměrně rozložit do dvou na sebe kolmých os, zaujímajících vztah „více ku méně“. Kódováním a bližším zkoumáním připravíme data pro jejich následné umístění mezi tyto osy, čímž vytvoříme poziční mapu. Pro účely poziční mapy lze využít nejrůznější druhy dat, jako jsou obrázky a texty, internetové zdroje, stejně tak data získaná pozorováním v terénu či etnograficky. Její hlavní výhodou je možnost zdůraznit heterogenitu zastávaných pozic, které mohou být často protichůdné. Přenesením problematiky na poziční osy může zachytit absenci či odchylku od běžných tendencí ve společnosti. Jednotlivé pozice nemusejí korelovat s osobami či kolektivními reprezentanty, ale jedná se o pozice v daném 
diskurzu. Poziční mapa je dostatečně dobrá tehdy, když už se při opětovném průchodu nevynořují nová zásadní témata či osy.

\section{Závěr}

Přestože se v našich podmínkách vyskytují výzkumy, které deklarují využití situační analýzy, jejich aplikace často končí ve fázi otevřeného kódování zakotvené teorie (srov. Čejková 2018; Vlčková 2017). Za inspirující proud domácí situační analýzy můžeme v současnosti označit pedagogicky (srov. Hanková a Vávrová 2017; Kalenda a Vávrová 2016) a sociologicky (srov. Karger 2019, 2017; Kalenda 2016b) orientované výzkumy.

Zahraniční výzkumy využívající situační analýzu dominují v oblasti péče o psychosociální zdraví (srov. Martin, Pauly a MacDonald 2016; French a Miller 2015; Gagnon, Jacob a Holmes 2015; Fulton a Hayes 2012) nebo v oblasti feministického výzkumu (srov. Barcelos 2017; Khaw 2012). Na rozdíl od prozatímní domácí scény se v zahraničí objevují i výzkumy zaměřené na konstruování vědění zpracované pomocí nástrojů situační analýzy. Př́ikladem může být studie zaměřená na konstrukci vědění mladých matek v sociálních a informačních světech (Greyson, O’Brien a Shoveller 2017) či analýza diskurzů, které ovlivňují vnímání násilí a sexuálního zneužívání žen u mladých mužů z Nikaraguy (Salazar, Goicolea a Öhman 2016).

V sociologii si SA našla své místo v německé a rakouské větvi především díky spolupráci Clarke s Reinerem Kellerem (2014, 2012). Významnou roli zde hraje i vzájemná epistemologická blízkost Kellerem (2011) reprezentované SKAD (Social Knowledge Approach to Discourse) a SA.

Zkoumání diskurzů v SA pomáhá odhalovat ustálené vzorce moci ${ }^{9}$ a privilegií, které bývají prosazovány či zamlčovány určitou ideologií. Mapováním diskurzů a jejich konstrukcí př́tomných ve vybrané promluvě či textu můžeme odhalovat pravidelnosti s cílem upozornit na strukturální charakteristiky konkrétního diskurzu (např. náboženský, lékařský, sociologický, multikulturní aj.), produkci (sociálních) identit v jazyce a způsob utváření vědění (Phillips a Hardy 2002). Zajímavé pro situační analýzu jsou i abnormality, netradiční konstrukce, přítomný teorém či záměrně zamlčovaná témata v situaci. Mluvčí používají různé interpretační repertoáry za účelem dosažení žádoucích účinků v dané sociální interakci. Jejich identifikace v každodennosti pomáhá stanovovat diskurzivní způsobilost mluvčích a diskurzivní vzorce, které komunikují a reprodukují sociálně sdílené významy (Harré a Gillet 2001) v jednotlivých sociálních světech a arénách. Jejich poznáním lze dosáhnout i určité sociální změny (např. narušení strukturální nerovnosti). To konvenuje s charakteristickým znakem postvýzkumných strategií, které se (mimo jiné) zaměřují na sociální změnu (mohou implicitně obsahovat tzv. sociální angažovanost) a orientaci na zdroje moci. Pro takový výzkum je typická reflexivita a interdisciplinarita, která pomáhá hledat efektivní intervenční strategie

9 Vedle státních složek, jako jsou policie nebo vojenské síly, které udržují moc prostřednictvím donucovacích technik, existuje, jak uvádí Althusser, ideologický státní aparát. V jeho perspektivě se jedná o instituce, jež organizují vztahy moci hlavně pomocí jazyka, nikoli donucovací silou (1971, s. 87-120). 
sociální spravedlnosti. Angažovaná kritika je typická pro postkoloniální diskurz ve vědě, ${ }^{10}$ který tematizuje patologie ve společnosti spojené se západní modernitou. Sama Clarke se v otázkách postkoloniálního pojetí vědy angažovala především ve feministicky orientovaných studiích. Její př́stup ovlivnil sociálně angažované vědce a de-kolonizující výzkumy (srov. Chen 2011; Milwertz a Fengxian 2011; Genat 2009).

Situační analýza se namísto předkládání nomologických hypotéz (objasnění zákonitostí jevů) vydává směrem k interpretativnímu pochopení utvářené a diskurzivně reprodukované sociální reality. Nástroje situační analýzy nám umožňují vyrovnat se jednostranným kauzalitám při interpretaci. SA podporuje multidimenzionalitu dat a jejich interpretaci variabilitou inherentních výzkumných přístupů i konkrétních nástrojů. Tím postihuje komplexitu bádaného sociálního fenoménu a naplňuje volání po holistickém řešení sociálních problémů, aniž by odmítala fragmentárnost a diverzitu sociálního světa (srov. Schut et al. 2014). Interdisciplinarita epistemologických prrístupů umožňuje spolupráci jinak úzce zaměřených výzkumných týmu a podporuje legitimitu SA, která nemůže zkoumat disparátní jevy v situaci odděleně. SA se snaží překonat pomyslné limity při zkoumání sociálních procesů prostřednictvím zkoumání celé situace a zachycením fundamentálních elementů, které se v ní vyskytují. Její nástroje mohou ocenit etnograficky orientovaní výzkumníci, kteří pracují s komplexitou zkoumané situace a disponují různým datovým materiálem, nebo sociálněvědní badatelé, kteří výzkumem kriticky artikulují strukturální nerovnosti, nespravedlnosti, exkluzi či zdroje moci a vědění ve společnosti.

Vlivem globalizace mluvíme o prostorové, časové, informační i zdrojové kompresi a zároveň akceleraci sociální a technologické. Zaměření i na nemateriální elementy zkoumané situace představuje kvalitativní metodologický potenciál pro alespoň částečné uchopení globálních struktur (např. ve formě sociálních uzlů), sociálních sítí a struktur moci. Sociální arény umožňují výzkumníkovi sledovat institucionální moc a řád, které nemusejí nutně působit v hierarchii instituce shora dolů, ale spíše jako mocenská sít' vztahů. Hovoř́me tak spíše o analýze relační ekologie než př́mé kauzalitě.

Komplexnost SA zároveň představuje určitou limitaci ve fázi prezentace a recepce výsledků. Mohlo by se zdát, že svojí snahou reprezentovat multiplicitu sociální reality ${ }^{11}$ (na rozdíl od zakotvené teorie, která realitu značně zjednodušuje) komplikuje celkové porozumění. Její aplikace zároveň vyžaduje výrazné souznění s konstruktivistickou teorií produkce vědění, čímž symbolicky zamezuje alternativnímu výkladu poznání (např. pozitivisticky orientovaného výzkumníka). Analytické zaměření na diference, zamlčované a odlehlé vztahy,

10 Postkoloniální přístupy zdůrazňují, že je zkoumání sociálních fenoménů v modernitě nemožné bez přihlédnutí ke koloniální historii. Nelson Maldonado-Torres (2017) hovoří o dekolonizaci např. západních (školních) institucí, jež by měly kriticky přistoupit k zažitému řádu pravdy, který často vnucují i ostatním kulturám. Mezi takovou pravdu autor řadí obhajobu moderny jako jediného smysluplného modu vivendi. V jeho podání by dekoloniální obrat ve vědě měl poctivě reflektovat koloniální historii a docenit marginalizované vědění kultur, které bylo modernitou umlčeno, převychováno či tzv. civilizováno.

11 Zde se nabízí přirovnání k výrazu messy map. Clarke považuje onu neuspořádanost za výhodu, protože skýtá prostor pro reflexi, výzkumnickou kreativitu/flexibilitu a hledání nových spojení, které se nemusely v úvodu jevit jako důležité. 
redefinici tradovaného vědění či explicitní reflexivitu výzkumníka vyžaduje odhodlání vzdorovat naučeným vzorcům a ochotu vytrvat v nestabilitě.

\section{Literatura}

ALTHUSSER, Louis. 1971. Lenin and Philosophy and Other Essays. New York: Monthly Review Press. BANKS, Marcus. 2001. Visual Methods in Social Research. London: Sage.

BARCELOS, Chrisie A. 2014. „Producing (Potentially) Pregnant Teen Bodies: Biopower and Adolescent Pregnancy in the USA." Critical Public Health 24(4): 476-488.

BERGER, Peter L. a Thomas LUCKMANN. 1999. Sociální konstrukce reality: Pojednání o sociologii vědění. Praha: Centrum pro studium demokracie a kultury.

BLUMER, H. 1969. Symbolic Interactionism: Perspective and Method. Englewood Cliffs: Prentice Hall.

BUCKINGHAM, D. 2011. The Material Child: Growing Up in Consumer Culture. Malden: Polity Press.

CHEN, Jia-shin. 2011. „Studying Up Harm Reduction Policy: The Office as an Assemblage.“ International Journal of Drug Policy 22(6): 471-477.

CLARKE, Adele E., Carrie FRIESE a Rachel WASHBURN (eds.). 2015. Situational Analysis in Practice. Mapping Research with Grounded Theory. London: Left Coast Press.

CLARKE, Adele E. a Reiner KELLER. 2014. „Engaging Complexities: Working against Simplification as an Agenda for Qualitative Research Today. Adele Clarke in Conversation with Reiner Keller.“ Forum Qualitative Sozialforschung / Forum: Qualitative Social Research 15(2): 1-40.

CLARKE, Adele E. a Reiner KELLER. 2012. Situationsanalyse. Grounded Theory nach dem Postmodern Turn. Wiesbaden: Springer VS.

CLARKE, Adele E. 2007. „Grounded Theory: Critiques, Debates, and Situational Analysis.“ Pp. 835-885 in William OUTHWAITE a Stephen P. TURNER (eds.). The SAGE Handbook of Social Science Methodology. London: SAGE.

CLARKE, Adele E. 2005. Situational Analysis: Grounded Theory After the Postmodern Turn. California: Sage Publications, Inc.

CLARKE, Adele, E. 2003. „Situational Analysis. Grounded Theory after the Postmodern Turn.“ Symbolic Interaction 26(4): 553-576.

ČEJKOVÁ, Ingrid. 2018. „Žákovské hodnocení výuky na gymnáziu: výpovědi sexty A.“Pedagogická orientace 28(3): 408-434.

FLETCHER, Isabel a Adele E. CLARKE. 2018. „Imagining Alternative and Better Worlds: Isabel Fletcher Talks with Adele E. Clarke." Engaging Science, Technology, and Society 4: 222-245.

FOUCAULT, Michel. 2002. Archeologie vědění. Praha: Herrmann \& synové.

FOUCAULT, Michel. 2000. Dohližet a trestat: kniha o zrodu vězení. Praha: Dauphin.

FULTON, John a Catherine HAYES. 2012. „Situational Analysis-Framing Approaches to Interpretive Inquiry in Healthcare Research.“ International Journal of Therapy and Rehabilitation 19(12): 662-669.

FRENCH, Martin a Fiona A. MILLER. 2012. „Leveraging the ,Living Laboratory“: On the Emergence of the Entrepreneurial Hospital.“ Social Science \& Medicine 75: 717-724.

GAGNON, Marilou, Jean D. JACOB a Dave HOLMES. 2015. „Governing Through (In)Security: A Critical Analysis of a Fear-Based Public Health Campaign.“ Critical Public Health 20(2): 245-256.

GIDDENS, Anthony. 2007. New Rules of Sociological Method: A Positive Critique of Interpretative Sociologies. Cambridge: Polity Press. 
GENAT, Bill. 2009. „Building Emergent Situated Knowledges in Participatory Action Research.“ Action Research 7(1):101-115.

GERGEN, Kenneth. J. 2008. „Social Construction: Revolution in the Making.“ Pp. 1-30 in Kenneth J. GERGEN (ed.). An Invitation to Social Construction (2nd Edition). London: SAGE.

GLASER, Barney G. 1992. Basics of Grounded Theory Analysis: Emergence Versus Forcing. Mill Valley, CA: The Sociology Press.

GREYSON, Davon, Heather O'BRIEN a Jean SHOVELLER. 2017. „Constructing Knowledge and Ignorance in the Social Information Worlds of Young Mothers." Proceedings of the Association for Information Science and Technology 54: 139-149.

HANKOVÁ, Magdalena a Soňa VÁVROVÁ. 2017. Partnerské vztahy očima mladých dospělých $s$ vrozeným tělesným postižením. Praha: Grada.

HARRÉ, Rom a Grant R. GILLET. 2001. Diskurz a mysel': úvod do diskurzívnej psychológie. Bratislava: Iris.

HJELM, Titus. 2011. „Discourse Analysis.“ Pp. 134-150 in Michael STAUSBERG a Steven ENGLE (ed.). The Routledge Handbook of Research Methods in the Study of Religion. Abingdon: Routledge.

CHARMAZ, Kathy. 2000. „Grounded Theory: Objectivist and Constructivist Methods.“ Pp. 509-536 in Norman DENZIN a Yvonna S. LINCOLN. Handbook of Qualitative Research (2nd Edition). Thousand Oaks, CA: Sage.

CHARMAZ, Kathy. 2006. Constructing Grounded Theory. A Practical Guide Through Qualitative Analysis. London: Sage.

KALENDA, Jan. 2016a. „Prozatím nevyužitá šance: situační analýza v pedagogickém výzkumu.“ Pedagogická orientace 26(3): 457-481.

KALENDA, Jan. 2016b. „Situational Analysis as a Framework for Interdisciplinary Research in the Social Science.“ Human Affairs 26(3): 340-355.

KALENDA, Jan a Soňa VÁVROVÁ. 2016. „Self-Regulated Learning in Students of Helping Professions." Procedia-Social and Behavioral Sciences 217: 282-292.

KARGER, Tomáš. 2019. „Mediální kurace jako praxe paměti: Situační analýza mnemonických praxí mládeže.“ Historická sociologie 11(1): 29-50.

KARGER, Tomáš. 2017. „Explanatory Principles in Research of Collective Memory: Culture, Cognition and their Situatedness." Historická sociologie 9(2): 23-40.

KISSOVÁ, Blanka, Romana LUKÁŠOVÁ a Daniel TOPINKA. 2018. „Institucionální pomoc v oblasti domácího násilí z perspektivy obětí domácího násilí v partnerském vztahu.“Czech \& Slovak Social Work/Sociální práce 18(2): 72-84.

KELLER, Reiner. 2011. „The Sociology of Knowledge Approach to Discourse (SKAD).“ Human Studies 34(1): 43-65.

KHAW, Lyndal. 2012. „Mapping the Process: An Exemplar of Using Situational Analysis in a Grounded Theory Study.“ Journal of Family Theory and Review 4: 138-147.

LAKOFF, George a Mark JOHNSON. 1999. Philosophy in the Flesh: The Embodied Mind and its Challenge to Western Thought. New York: Basic Books.

LUHMANN, Niklas. 2006. Sociální systémy. Brno: CDK.

MALDONADO-TORRES, Nelson. 2017. „On the Coloniality of Human Rights.“ Revista Critica de Ciências Sociais 114: 117-136.

MARTIN, Wanda, Bernie PAULY a Marjorie MACDONALD. 2016. „Situational Analysis for Complex Systems: Methodological Development in Public Health Research.“ AIMS Public Health 3(1): 94-109.

MEYER, Renate E., Markus A. HÖLLERER, Dennis JANCSARY a Theo Van LEEUWEN. 2013. „The Visual Dimension in Organizing, Organization, and Organization Research.“ Academy of Management Annals 7(1): 489-555. 
MILWERTZ, Cecilia a Wang FENGXIAN. 2011. „The Relational and Intra-Active Becoming of Nongovernment-Initiated Organizing in the People's Republic of China." Gender, Technology and Development 15(3): 457-483.

PHILliPS, Nelson a Cynthia HARDY. 2002. Discourse Analysis: Investigating Processes of Social Construction. London: SAGE, CA: Thousand Oaks.

POTTER, Jonathan. 2000. „Post-Cognitive Psychology.“ Theory \& Psychology 10(1): 31-37.

ROSE, Gillian. 2012. An Introduction to the Interpretation of Visual Materials. London: Sage Publication.

SACKS, Harvey. 1992. Lectures on Conversation. Oxford: Blackwell.

SALAZAR, Mariano a Ann ÖHMAN. 2015. „Negotiating Masculinity, Violence, and Responsibility: A Situational Analysis of Young Nicaraguan Men's Discourses on Intimate Partner and Sexual Violence.“ Journal of Aggression, Maltreatment \& Trauma 24(2): 131-149.

SCHUT, Marc. et al. 2014. „Towards Dynamic Research Configurations: A Framework for Reflection on the Contribution of Research to Policy and Innovation Processes." Science and Public Policy 41: 207-218.

STANKOVÁ, Zuzana. 2020. „Zdroje podpory sociálního začleňování: perspektiva sociálních pracovníků působících v sociálně vyloučených lokalitách na území Moravskoslezského kraje. “Czech \& Slovak Social Work/Sociálni práce 20(2): 61-78.

STRAUSS, Anselm L. 1978. „A Social Worlds Perspective.“ Studies in Symbolic Interaction 1: 119-128.

STRAUSS, Anselm L. a Juliet CORBIN. 1999. Základy kvalitativního výzkumu: Postupy a techniky metody zakotvené teorie. Boskovice: Sdružení Podané ruce.

SUDDABY, Roy. 2006. „What Grounded Theory is Not.“ Academy of Management Journal 49(4): 633-642.

TŮMA, František. 2016. „Konverzační analýza a interakce ve třídě: východiska a metodologické aspekty." Pedagogická orientace 26(3): 415-441.

van DIJK, Teun A. (ed.). 2006a. Discourse Studies: A Multidisciplinary Introduction. London: SAGE. van DIJK, Teun A. 2006b. „Discourse, Context and Cognition.“ Discourse Studies 8(1): 159-177.

van DIJK, Teun A. 1988. News as Discourse. Hillsdale, NJ: Lawrence Erlbaum Associates.

VENTEROVÁ, Lenka. 2018. „Home Preparation of Anglophone Children for School: The Influence of a Different Culture.“ Sociální pedagogika/ Social Education 6(2): 27-42.

VLČKOVÁ, Kristýna. 2017. „Rozhodování rodičů o odkladu školní docházky v kontextu výběru školy.“ Orbis scholae 11(1): 31-50.

VOJTÍŠKOVÁ, Kateřina. 2008. „Studium sociální struktury jako konstruovaného prostoru. Sociální kategorizace a sociální identita." Pp. 61-78 in Jiří ŠAFR (ed.). Sociální distance, interakce, relace a kategorizace: alternativní teoretické perspektivy studia sociální stratifikace. Praha: Sociologický ústav Akademie věd České republiky.

WODAK, Ruth a Michael MEYER. 2001. Methods of Critical Discourse Analysis. London: SAGE.

WOOFFITT, Robin. 2005. Conversation Analysis and Discourse Analysis: a Comparative and Critical Introduction. London: SAGE.

YOUNG, Iris M. 2007. Global Challenges. War, Self-Determination and Responsibility for Justice. Cambridge: Polity Press.

ZÁBRODSKÁ, Kateřina. 2009. Variace na gender: poststrukturalismus, diskurzivni analýza a genderová identita. Praha: Academia. 


\section{Autorka}

Markéta Košatková působí jako odborná asistentka na Katedře sociální pedagogiky Masarykovy univerzity. Jejím výzkumným zájmem je sociální a strukturální útlak, který brání rovným příležitostem ve vzdělávání. Zaměřuje se na potenciál kvalitativních analýz, nejčastěji na diskurzivní, situační a vizuální př́stupy v sociálních vědách. V praxi působí proaktivně v otázkách diverzity a interkulturního dialogu.

Kontakt: kosatkova@mail.muni.cz 